\title{
Contribution of Bishops of České Budějovice to Care of the III in their Town of Residence in 1785-1883'
}

\section{Rudolf Svoboda}

\section{A few words of introduction}

Concerning care for persons in need, scholarly literature has so far paid attention especially to works of charity, developed in the diocese of České Budějovice in the first century of its existence by individual activities of the bishops as well as by local parish charities, which were set up by state edict in the Josephine period and carried on with their activity also in the following century. ${ }^{2}$

A topic that has been rather neglected so far is how the local church was involved in the sphere of caring for the ill. In general one can say that at the time when the diocese of České Budějovice was established at the end of the eighteenth century, there was as yet no clear division between charity and health care institutions. Clear differentiation and especially increase in the number of hospitals took place gradually in the course of the nineteenth century, due not only to state edicts striving to increase the quality of life and health care and of supervision over the qualification of physicians, but also to more intensive financial support on the part of local governments and the Church. ${ }^{3}$

In this short study we will illustrate this issue on the activities of the first four bishops of České Budějovice Jan Prokop Schaaffgotsche, Arnošt Konstantin Růžička, Josef Ondřej Lindauer and Jan Valerián Jirsík, especially in the context of their concern for the ill in their town of residence.

\section{Jan Prokop Schaaffgotsche and Arnošt Konstantin Růžička}

For the first bishop of České Budějovice Jan Prokop Schaaffgotsche (1785-1813) care of the ill became one of the important activities of his episcopate. He knew very well that the situation in the newly founded diocese (1785) and in his town of residence was not very good in this respect. Official documents show that at the time of his installation in office

\footnotetext{
1 This study is published with kind support of the Czech Science Foundation as partial output of the project 15-09797S "Jan Valerián Jirsík: život a teologické dílo".

2 Cf. Rudolf SVOBODA, Počátky českobudějovické diecéze, Praha: Vyšehrad, 2014; Martina HALÍŘOVÁ, Role duchovních v chudinské a nalezenecké péči, Historie - Otárky - Problémy 2/2009 (Od barokní piety k interiorizaci víry? Problémy katolického osvícenství v českých zemích), pp. 133-137.

3 Cf. Zdeňka STOKLÁSKOVÂ, Osvícenství a vznik veřejného zdravotnictví, in: Post tenebras spero lucem. Duchovní tvár českébo a moravského osvícenství, eds. Daniela TINKOVÁ - Jaroslav LORMAN, Praha: Cassablanca - Filozofická fakulta UK, 2009, pp. 88-105; in more detail on the topic Daniela TINKOVÁ, Zákeřná mefitis. Zdravotní policie a veřejná bygiena v pozdně osvícenských Čechách, Praha: Argo, 2013.

4 On his life and especially episcopal activity the following monographs have been published: Rudolf SVOBODA, Jan Prokop Schaaffgotsche: První biskup českobudějovický, Brno: L. Marek, 2009 and Rudolf SVOBODA, Jobann Prokop Schaffootsch. Das Leben eines böbmischen Prälaten in der Zeit des Josepbinismus (= Beiträge zur Kirchen- und Kulturgeschichte 25), Frankfurt am Main, Berlin, Bern, Bruxelles, New York, Oxford, Wien: Peter Lang, 2015.
} 
there were eighty-five poorhouses in the diocese that may have provided some sort of health care and only three hospitals. ${ }^{5}$

Bishop Schaaffgotsche emphasized the necessity to help the ill already in his first pastoral letter of January $1^{\text {st }}, 1786$, addressed to the inhabitants of the diocese, in which he quite clearly formulates the need to care for the spiritual aspect of each of the faithful. ${ }^{6}$ Taking care of better health care for the inhabitants belonged, among others, to the clerical vocation, as the Josephinian state of the time understood it. ${ }^{7}$

Unfortunately, the new diocese was not rich. Schaaffgotsche himself had hardly any other income than the not very high bishop's salary paid out by the state. In the turbulent times of the Napoleonic wars it was very difficult to realize almost any construction or foundation projects for lack of funds. Information on the disconsolate material backing of health care is provided by the report of the general visitation from the end of Schaaffgotsche's almost thirty years long episcopate, in which the bishop states that 361 persons were living in hospitals and poorhouses which, compared to the almost three quarters of a million inhabitants of the diocese, really was not much. ${ }^{8}$ But on the other hand he states that priests take care of the ill from the spiritual point of view, so that no ill person died without being provided for with sacraments by fault of the responsible spiritual administrator. ${ }^{9}$

Bishop Schaaffgotsche's personal involvement can be seen primarily in his concern for the ill in České Budějovice. At the time the episcopate was founded two institutions provided

5 Cf. Archivio Segreto Vaticano (dále jen ASV), Archivium Consistorialis (dále jen AC), Acta Congregationis Consistorialis 1785, Pars I, 1785 Budvicen. Erectionis in Episcopalium, fol. 273-297; ASV, AC, Processus Consistorialis - Processus Inquisitionis super statu Ecclesiae Budvicen. nunc primum auctoritate Apostolica in Cathedralem erigendae, et super qualitatibus Rmi. Dni. Joannis Procopii Comitis de Schafgotsch Metropolitanae Ecclesiae Olomucen. Canonici ad Episcopatum Budvicen. dicta auctoritate promovendi 1785, fol. 137-183; Congregazione del Consilio, Relationes Dioecesium (fine sec. XVI - 1890 circa), Budvicen., Ceske Budejovice - Budweis (Bohemia), sign. 153, fol. 138-147.

6 Transcription of the pastoral letter of Jan Prokop Schaaffgotsche of January $1^{\text {st }}, 1786$ see Franz MARDETSCHLÄGER, Kurz gefasste Geschichte des Bistums und der Diöcese Budweis zur Jubiläumsfeier ibres bundertjäbrigen Bestehens, Budweis: Franz Mardetschläger, 1885, pp. 274-283. Draft of the pastoral letter see SOA Třeboň, Biskupský archiv České Budějovice (further BA ČB), Pastýřské listy biskupa Schafgotsche, 1786-1795, sign. II/1/b/10, kart. 11.

The text says: "Sitis sal terae, cujus virtute condiantur fideles vestri. Nolite distinguere inter Judaeum, et Graecum, sed omnes eadem charitate, eodem amore, eodem zelo complectamini. Sitis miseris solamen, affictis consolatio, pauperibus refugium, infirmis adjutorium, debilibus fortitudo, dubitantibus consilium, ignorantibus instructio, oppressis defensio, innocentiae custodia, lapsis resurrectio, spiritualiter mortuis vita; Vigilate in omnibus laborate opus faciatis Evangelistae, ministeriumque vestrum implete, coram Deo et Christo Jesu..." ("Let you be salt of the earth, by whose power your faithful are seasoned. Do not distinguish between Jew and Greek, encompass all with the same respect, the same love, the same zeal. Be comfort to the miserable, consolation to the afflicted, refuge to the poor, assistance to the weak, advice to the doubting, instruction to the ignorant, defence to the oppressed, guard to the innocent, rising again to those who have fallen, life to the spiritually dead; be watchful in everything and labour to do the work of the Evangelist, and fulfil your ministry before God and Jesus Christ...", translated by author).

See also Rudolf SVOBODA, Seid den Armen Zuflucht und den Kranken Hilfe, in:, Theorie und Praxis der Karitativen Arbeit, Einfübrung in die Problematik, Praktische Reflexion und Anwendung, eds. Michal OPATRNÝ - Markus LEHNER, České Budějovice: Teologická fakulta JU (Edice Scientia Bd. 5), 2010, pp. 10-26.

7 Cf. Claude MICHAUD, Der Josephinismus in der Habsburgermonarchie (1740-1790), in: Die Geschichte des Christentums: Aufklärung, Revolution, Restauration (1750-1830), ed. Norbert BROX, Freiburg im Breisgau - Basel - Wien: Herder, 2000, pp. 23-24; Rudolf LEEB - Maximilian LIEBMANN - Georg SCHEIBELREITER - Peter G. TROPPER, Geschichte des Cbristentums in Österreich. Von der Spätantike bis zur Gegenwart, Wien: Verlag Carl Ueberreuter, 2003, pp. 296-297; Martina HALÍŘOVÁ, Role duchovních v chudinské a nalezenecké péči, pp. 133-134.

8 Cf. Österreichisches Staatsarchiv Wien, Haus-, Hof- und Staatsarchiv (further only HHSA), Kaiser-Franz-Akten 215, sign.

AT-OeStA/HHSTA KA KFA, fol. 524-571.

Cf. Kurt Augustin HUBER, Der Budweiser bischöfliche Visitationsbericht von 1811, in: Archiv für Kirchengeschichte von BöbmenMäbren-Scblesien VII, Festschrift zur zweiten Säkularfeier des Bistums Budweis 1785-1985, ed. Kurt Augustin HUBER, Königstein im Taunus: Institut für Kirchengeschichte von Böhmen-Mähren-Schlesien, 1985, p. 72.

9 Cf. Österreichisches Staatsarchiv Wien, HHSA, Kaiser-Franz-Akten 215, sign. AT-OeStA/HHSTA KA KFA, fol. 397-398; SOA

Třeboň, BA ČB, Report of the bishop to the provincial government on the state of the diocese, 1811, $\mathbb{S} 2$, sign. II/1/b/7, kart. 10. 
at least some sort of health care there: Since early $14^{\text {th }}$ century there had been a hospital with the church of St. Wenceslas, abolished in $1786,{ }^{10}$ and there was the municipal poorhouse (Armeninstitut) in what is now Krajinská avenue, founded in 1781, administrated for a short time by sisters of the order of St. Francis. In 1787 care in the poorhouse was extended to hospital nursing and in 1793 it was merged with the municipal hospital. But the capacity of the building was small and the situation of hospital care certainly was not good for a town of five thousand inhabitants. ${ }^{11}$

Schaaffgotsche was unable to solve the situation with hospital care in his own town of residence, despite the fact that he closely cooperated with representatives of the town headed by the mayor Franz Daudlebský von Sterneck, of whom it was known that besides schooling he devoted much attention precisely to care of the poor and the $i l l .{ }^{12}$ Despite all effort they did not succeed to accumulate sufficient means for the common project of building a new hospital.

Until the end of Schaaffgotsche's episcopate it held that the town took care of the material aspect of the functioning of the existing "hospital" and the Church provided spiritual administration, in which the bishop was personally involved by regular visits and providing sacraments to the ill, as testified by records in so-called Book of Episcopal Works. ${ }^{13}$ But he never forgot the need for the new hospital, which is documented by his testament of 1813, in which he left a significant part of his legacy for its construction, the sum of 3815 florins. ${ }^{14}$ For completeness's sake we must add that precisely his concern for the ill and the dying became part of his spiritual legacy for the subsequent generations. ${ }^{15}$

Schaaffgotsche's successor Arnošt Konstantin Růžička (1813-1845), who had stood by his side as vicar general for almost two decades, continued in his legacy. ${ }^{16} \mathrm{He}$ also faced the fact

10 Cf. Daniel KOVÁ ̌̌, Zdravotní péče, in: Encyklopedie Českých Budějovic (further only EČB), České Budějovice: Statutární město České Budějovice - Nebe, 2. vydání, 2006, p. 636. Elsewhere the year when the hospital was abolished is stated as 1796. See Daniel KOVÁŘ - Diana ŠMAJCLOVÁ - Jiří ČERNÝ, Nemocnice, EČB, p. 343. This discrepancy can be explained as follows: In 1786 the Franciscan sisters left town and thereby their engagement in the hospital ended. With support of the municipality the hospital probably functioned for ten more years. Then it was definitively abolished.

11 Cf. Karel PLETZER, Chudobinec, EČB, p. 184; Jiří KROPÁČEk - Oldřich MIKULA, Sociální péče, EČB, p. 510.

12 Cf. Robert SAK - Václav BU゚ŽEK - Jiří DVOŘÁK - Miroslav NOVOTNÝ, Dějiny města, EČB, p. 92.

13 According to records in the Book of Episcopal Works the bishop visited altogether 125 ill persons and provided sacraments to them. See S. Penitentia Eucharistia et Unctionis sacramentis, SOA Třeboň, BA ČB Matrika biskupských prací - Matrica seu Liber functionum episcopalium, 1786-1852, inv. no. 17, book 17. Franz Mardetschläger states 122 faithful provided with the last sacraments. Cf. Franz MARDETSCHLÄGER, Kurz gefasste Geschichte, p. 14.

The so-called episcopal diary also testifies to personal visits to the ill. SOA Třeboň, BA ČB, Makulár matriky biskupských prací

- Macularie diarii et functionum episcopalium, 1789-1799, inv. no. 16, book 16.

14 Cf. Willibald LADENBAUER, Das Soziale Wirken der katholischen Kirche in der Diöcese Budweis (Königreich Böhmen) von Dr. P. Willibald Ladenbaner, Wien: Commissions-Verlag von Maner a Co., 1899 (= Das Sociale Wirken der Katholischen Kirche in Oesterreich. Im Auftrage der Leo-Gesellschaft und mit Unterstützung von Mitarbeitern herausgegeben von Prof. Dr. Franz M. Schingler, IX. Band: Diöcese Budweis), p. 257; Rudolf SVOBODA, Jan Prokop Schaaffotsche, pp. 247-248; Franz MARDETSCHLÄGER, Kurz gefasste Geschichte, p. 16.

15 Cf. Biographisches Lexikon des Kaisertbums Oesterreich enthaltend die Lebensskizzen der denkwürdigen Personen, welche seit 1750 in den österreichischen Kronländern geboren wurden oder darin gelebt und gewirkt baben, ed. Constantin WÜRZBACH, Wien: Druck und Verlag der k. k. Hof- und Staatsdruckerei, 1875, p. 83; Jaroslav KADLEC, Českobudějovická diecéze, České Budějovice: Sdružení Jana Nepomuka Neumana - Setkání, 1995, p. 28; Rudolf SVOBODA, Legenda o dobrém pastýrí, Verba theologica 1/2009, pp. 24-29. 16 On the life of A. K. Růžička see the monograph Rudolf SVOBODA, Arnošt Konstantin Rĩžička: Josefinista na českobudějovickém biskupském stolci, České Budějovice: Jih, edition Středoevropské dějiny, vol. 4, 2011. 
of an insufficient number of health care institutions in the diocese. ${ }^{17}$ Just as his predecessor had done, he admonished the faithful to perform deeds of Christian love among others by serving the ill. ${ }^{18}$

In cooperation with representatives of the town of České Budějovice it was eventually possible to build a new hospital, for which bishop Schaaffgotsche had strived so much. The money from his legacy was used to buy a piece of land in 1826. Master builder Josef Bednařik was commissioned to work out the plans. ${ }^{19}$ Bishop Rưžička personally attended the laying of the foundation stone on May $21^{\text {st }}, 1827$. The two-storeyed building, situated on the inner edge of the then Viennese suburb in the mouth of what is now Karel IV. street to Mlýnská stoka, was finally approved on October $4^{\text {th }}, 1829$ and then ceremonially opened on December $24^{\text {th }}$ of the same year with the bishop attending. The total construction cost was 18918 florins. Růžička himself made a contribution, presenting a thousand florins. The rest was paid for by the town. The building went under the title Bürgerliches Armen - Kranken und Arbeitshaus and served simultaneously as a poorhouse. Its operation was directed by representatives of the town, physicians and the Church, the spiritual administrator of the hospital was the town dean. ${ }^{20}$ Rủžička himself took further care of the running of the hospital and designated money to support it in his testament. ${ }^{21}$ This institution became something the town could be proud of in a good sense of the word: when Emperor Ferdinand V visited České Budějovice on September $5^{\text {th }}, 1834$, he was among others taken to the new hospital. ${ }^{22}$

\section{Josef Ondřej Lindauer and Jan Valerián Jirsík}

Růžička’s successor Josef Ondřej Lindauer (1846-1850) only served as bishop for a short time, but nonetheless left a fairly essential legacy in this respect. ${ }^{23}$ He was a man who did not like to take unpremeditated steps in the sphere of helping the needy, due to which the limited means would be uselessly wasted.

17 ASV, AC, Processus Consistorialis - Processus Inquisitionis super Qualitatibus Rmi Dni Ernesti Ruziczka Cathedralis Ecclesiae Budvicensis Vicarii Generalis et Officialis ab Augustissimo Austriae Imperatore Francisco I Hungariae Apostolico, ac Bohemiae Rege ad Episcopatum Budvicensem Nominati, ac Promovendi et super Statu Ecclesiae Cathedralis Budvicensis Anno 1815, fol. 98-101.

18 Pastoral letter of Arnošt Konstantin Růžička of December 1831. See SOA Třeboň, BA ČB, Arnošt Konstantin Růžička, Pastýřský list Arnošta Konstantina Rủžičky s udělením církevního dispensu od půstu pro postižené cholerou - tisk, 1831, sign. II/2/b/8, kart. 13.

19 For the oldest literary mention of this project see Ernst Franz RICHTER, Kuragefaßte Geschichte der k. befreiten allezeit getreuen Berg- und Kreisstadt Böbmisch-Budweis, Budweis: F. Zdarssa, 1859, pp. 43-44, 47. Josef Bednař́k was active in České Budějovice in 1818-1851. Besides building the hospital he also realized constructions of private houses. Cf. Daniel KOVÁŘ, Stavitelé, EČB, p. 536.

20 Cf. Daniel KOVÁŘ - Diana ŠMAJCLOVÁ - Jiří ČERNÝ, Nemocnice, EČB, p. 343; Jiří KROPÁČEK - Oldřich MIKULA, Sociální péče, $E \check{C} B$, p. 510. Karel Pletzer uses the name Armen Kranken und Korrektionsanstalt for the new institution. Cf. Karel PLETZER, Chudobinec, $E \check{C} B$, p. 184.

21 According to his testament of 1831 as well as the one of 1844 Růžička left a thousand florins to the hospital. See the testament of bishop Arnošt Konstantin Růžička of September 22 ${ }^{\text {nd }}$, 1831 and the testament of bishop Arnošt Konstantin Růžička of January $10^{\text {th }}$, 1844. Cf. SOA Třeboň, BA ČB, Arnošt Konstantin Růžička, Poslední vůle a pozůstalostní řízení, 1831-1848, sign. II/2/a/3, kart. 13; further also Willibald LADENBAUER, Das Soziale Wirken der katholischen Kirche in der Diöcese Budweis, pp. 257, 298; Jiří ČERNÝ - Diana ŠMAJCLOVÁ, Dějiny českobudějovické nemocnice, 1. díl, (středověk - 1948), České Budějovice: Nemocnice České Budějovice, 2007, pp. 18-20; Rudolf SVOBODA, Arnošt Konstantin Rů̌̌ička, pp. 151-153, 182-183.

22 Cf. Ernst Franz RICHTER, Kurzgefaßte Geschichte, pp. 45-47; Karel PLETZER, Návštěvy panovníků a prezidentů, EČB, p. 341; Franz MARDETSCHLÄGER, Kurz gefasste Geschichte, p. 21.

23 On Lindauer's life and episcopal activity see Rudolf SVOBODA, Josef Ondřej Lindauer - známý i neznámý třetí biskup českobudějovický, Jibočeský sborník bistorický 82/2013, pp. 153-163. 
As bishop he tried to proceed systematically in the diocese. He used the system of diocesan church administration and ordered the superiors of the thirty vicariates to send not only reports of the state of schooling and support of poor pupils, but also information on the number and support of the deaf-mute and the blind and on hospitals each September. ${ }^{24} \mathrm{His}$ concern for setting up new hospitals was well known - in particular he was able to support the hospitals in Strakonice and in Písek, with his authority or even financially. ${ }^{25}$

Unprecedented was his support of the hospital in České Budějovice, to which he presented 3 thousand florins shortly after his arrival in town. In 1849 he introduced the Merciful Sisters of St. Charles Borromeo to it, which is regarded as one of the greatest enterprises of his episcopate. He had had long-term experience with the Borromeo sisters during his activity as Prague canon, when he had been a contributing member of the society supporting blind adults in Bohemia - Versorgungs- und Beschäftigungs-Anstalt für erwachsene Blinde in Böbmen. An important context is that this society had been closely linked precisely with the Prague activity of Borromeo sisters to the benefit of blind persons already since $1837 .{ }^{26}$ There was good experience with the sisters in the diocese of České Budějovice as well, from their activity in Třeboň under the patronage of the Schwarzenberg family since 1841. Besides, they were in a sense returning home, since the very beginnings of Borromeo sisters in Bohemia were linked with the departure of four women from České Budějovice to the French town of Nancy, from where they returned in 1837 as nuns. The first superioress of the Borromeo sisters of České Budějovice Karolína, Johana by secular name, was a sister of the Philadelphia bishop and later saint Jan Nepomuk Neumann. ${ }^{27}$ According to historian Franz Mardetschläger 14 sisters came to České Budějovice during Lindauer's episcopate, of which 8 worked in the hospital and 6 in the orphans' asylum (Weisenbaus). The Borromeo sisters took over the administration of the hospital on January $9^{\text {th }}, 1850$. Lindauer presented 4 thousand florins for the beginning of their activity in the hospital. ${ }^{28} \mathrm{He}$ also made the hospital his universal heir. After the bishop's premature death the hospital received approximately 24 thousand florins from his legacy, which was a really great sum at the time. ${ }^{29}$ The grateful inhabitants

\footnotetext{
24 See Conspectus Relationum, quae singulis mensibus a Vic. For. Officiis ad Reverendissimum Episcopale Consistorium exhibendae sunt. Catalogus Universi Cleri tum Saecularis tum Regularis Episcopalis Dioeceseos Bohemo-Budvicensis of $1848-1851$.

25 SOkA Strakonice, Strakonice - Journal oder Merkwürdigkeiten und Vorfälle der Strakonitzer Haupt Schule, 1806-1859, school chronicle; Časopis pro katolické duchovenstvo (further ČKD) 3/1850, p. 198.

26 Cf. Augustin (Josef) SVOBODA, Milosrdné Sestry, živé vypodobnění Ježíše Krista. Řeč, při slavném činění slibů milosrdných sester ze shromáždění sv. Karla Boromea (Merciful Sisters, Living Image of Jesus Christ. Speech at Solemn Vow Making of Merciful Sisters of the Congregation of St. Charles Borromeo), ČKD 2/1850, pp. 133-150. The speech was delivered on August $15^{\text {th }}, 1848$ in Prague in the sisters' mother house. The author was doctor of theology and chaplain in Lišov. The author mentions they had come from France in 1837, they founded first the mother house in Malá Strana with a hospital. He then enumerates nine other institutions founded by them - hospitals or special institutes devoted to orphans or the blind. The last one he mentions is the hospital in České Budějovice: "Finally in České Budějovice, where the institute is established by their noble activity and by the own great cost of the Most Reverend bishop of the town, Mr. Ondřej Lindauer, and other benefactors." Ibid, p. 150. Further see e.g. Miroslav NOVOTNÝ, Řády a kongregace, $E \check{C} B$, p. 481.

27 She is mentioned as the superioress of the sisters in the poorhouse since 1849 . Whether she was since 1850 in charge also of the sisters in the hospital we have not yet been able to find out. Cf. Eva PĚSTOVÁ, Boromejky - aktivity ve 20. stoletív Praže, České Budějovice, 2015, bachelor's thesis, University of South Bohemia in České Budějovice, Faculty of Theology, Department of Theological Studies, thesis supervisor Martin Weis, pp. 9-11. The author used the unpublished manuscripts of the Borromeo sister Sebastiana Veselská Sestra Karolina, Jan Neuman and 150 let boromejek of 2011; further also Petra PFEFFROVÁ,

Sociálně-charitativní dílo spjatés rodným domem J. N. Neumanna, České Budějovice, 2014, bachelor's thesis, University of South Bohemia in České Budějovice, Faculty of Theology, Department of Theological Studies, thesis supervisor Martin Weis, p. 14. 28 Cf. Jiří ČERNÝ - Dana ŠMAJCLOVÁ, Dějiny českobudějovické nemocnice, pp. 10, 25; Franz MARDETSCHLÄGER, Kurz gefasste Geschichte, pp. 33, 157-158.

29 Cf. Franz MARDETSCHLÄGER, Kurz gefasste Geschichte, p. 38. See also SOA Třeboň, BA ČB, kart. 14.
} 
of the town had a monument built at the Old Town cemetery of České Budějovice with a thanksgiving for precisely this great gift. ${ }^{30}$

At the time of the episcopate of Jan Valerián Jirsík (1851-1883) ${ }^{31}$ basic institutionalization of health care in the diocese and in his town of residence had already been secured and further specialization of health-social assistance followed. An example may be especially the fact that the Borromeo sisters ran the hospital until June $30^{\text {th }}, 1856$, then it was handed over to municipal administration, but the nuns continued to take part in its operation. Of course, the Church still provided spiritual care of the ill. In Jirsík's time, in 1864 and 1873, the building was enlarged and number of beds increased. ${ }^{32}$ Private physician's offices and nursing homes also began to spring up in town. The number of specialists among the private physicians rose. Public care was provided by two physicians, in 1870 the office of regional physician was set up, who supervised health care at regional level. Since 1883 health care paid for by the municipality was directed by the town physician with the assistance of two town surgeons. ${ }^{33}$

Although it might seem that in this situation the Church could contribute only by spiritual care of the ill, the bishop thought otherwise. He saw a great gap in the health-social system, which was care of a group of persons with a very specific handicap - the deaf-mute. According to contemporary official reports there were more than 4 thousand deaf-mute persons in Bohemia, of that more than a thousand in his diocese. He was convinced that these persons must be taken care of and especially the children provided with schooling. He therefore sent a capable priest to train for work with these children in Prague. In 1870 he succeeded to obtain the building of the former teachers' institute in the present Riegrova street for teaching deaf-mute children, which he ceremonially opened on November $6^{\text {th }}$, 1871. The institute for the deaf-mute in České Budějovice was the fifth establishment of this kind in the Czech lands. Teaching was provided by the School Sisters de Notre Dame from Horažd'ovice. Care for deaf-mute children was the bishop's pet project until his death, as manifested by personal care and frequent visits. As an altogether practical man Jirsík also took care of the institute's financing. He founded the Society for Maintaining the Institute of the Deaf-Mute (1871-1956). The Institute's operation was also supported by private donors and various trusts. The Institute itself gradually grew and was reorganized several times while in 1871 it began with 14 children and 3 teachers, already in 187350 children were

\footnotetext{
30 On October $2^{\text {nd }}, 1854$ a monument was consecrated, devoted to Lindauer from the gratitude of the faithful of České Budějovice for the fact that he gave a great part of his property for building the municipal hospital and invited the Borromeo sisters who took care of the ill. However, it is not erected over the bishop's grave, but fifteen steps from the cemetery entrance, at present approximately in the middle of the southern part of the cemetery premises. The monument was designed by sculptor Emanuel Max. It is carried out in neo-gothic style in the shape of a conical column, on which there is a relief of the bishop's sign and the inscription: "Reverendissimo Episcopo Budvicensi ANDREAE IOSEPHO LINDAUER benefactori nosocomii Budvicensis generoso, nato Pilsnae die 29. Nov. 1784, die 4. Junii 1850, 4to Episcopatus sui anno ex hoc saeculo egresso, grata Civitas Budvicensis. Requiescat in pace Domini!” Cf. Franz MARDETSCHLÄGER, Kurそ gefasste Geschichte, pp. 38-39; Úmrtí, ČKD 3/1850, p. 198.

31 On the life and work of Jan Valerián Jirsík see Jaroslav KADLEC, Jan Valerián Jirsík, České Budějovice: Setkání, 1993; Rudolf SVOBODA - Soňa KAMENOVÁ - Radka NOVOTNÁ, The Life And Theological Work of Jan Valerián Jirsík - Actual State of Research Issue, Notitiae bistoriae ecclesiasticae 1/2013, pp. 15-19.

32 Cf. Jiří ČERNÝ - Dana ŠMAJCLOVÁ, Dějiny českobudějovické nemocnice, pp. 10, 25; Daniel KOVÁŘ - Diana ŠMAJCLOVÁ - Jiř́ ČERNÝ, Nemocnice, EČB, p. 343.

33 Cf. Daniel KOVÁŘ, Zdravotní péče, $E \check{C} B$, p. 636.
} 
placed there and it was necessary to enlarge the building. In the 1880s the institute already took care of more than 80 children each year. ${ }^{34}$

\title{
A few words to conclude
}

Based on what has been said above we can say that for the first four bishops of České Budějovice care of the ill was an essential part of their activity, which they carried out with significant personal involvement. They did not focus only on spiritual care, but contributed also to institutional development of hospital care, especially in their town of residence. It is therefore quite certainly possible to say that they merited the appreciative remembrance of future generations.

\section{Contribution of Bishops of České Budějovice to Care of the III in their Town of Residence in 1785-1883}

\begin{abstract}
The study deals with the concern of the first four bishops of České Budějovice - Jan Prokop Schaaffgotsche, Arnošt Konstantin Rủžička, Josef Ondřej Lindauer and Jan Valerián Jirsík - for the ill in 1785-1883, with emphasis on their activities in České Budějovice. The study shows how concern for the ill was linked to works of charity, which were closely connected with spiritual care in the last decades of the eighteenth century. It then captures the process of gradual separation of charity and health institutions in the course of the nineteenth century, whereby an outward sign of this process was an increase in the number of hospitals. This was due to state edicts striving to increase the quality of life, health care as well as supervision over physicians' qualifications, but also to more intensive financial support on the part of local governments, and of course also to the all-round support of the Catholic Church represented by its bishops.
\end{abstract}

Keywords: České Budějovice, care of the ill, spiritual care, bishops, $18^{\text {th }}$ century, $19^{\text {th }}$ century

\section{Contact}

Assoc. Prof. Dr. Rudolf Svoboda

University of Souht Bohemia, České Budějovice

Faculty of Theology, Department of Theological Disciplines

Kněžská 8, 37001 Čské Budějovice

svobodar@tf.jcu.cz

34 Cf. Jaroslav KADLEC, Jan Valerián Jirsik, pp. 77-78; Miroslav NOVOTNÝ, Ústav hluchoněmých, EČB, p. 592; Franz MARDETSCHLÄGER, Kur gefasste Geschichte, pp. 68-70. Statutes of the Society for Maintaining the Institute for the Deaf-Mute in České Budějovice of 1871 and yearly reports of the Institute until 1873 are available in SOkA České Budějovice, sign. C 44. 